\title{
How Kant Thought He Could Reach Hume
}

\author{
Charles Goldhaber
}

\section{Kant's aims in the deduction}

A traditional and still prevalent interpretation of the Critique of Pure Reason's transcendental deduction of the categories attributes to Kant the aim of refuting skepticism. Presumably, the arguments in the deduction are meant to justify the application of the categories to the objects of experience in a way that answers the skeptic's challenge.

Various skeptics have seemed to be Kant's target. For the sake of this discussion, I consider only skeptical empiricists. Such figures, among whom Kant counted Hume, hold that all concepts derive from experience. And that leads them to doubt or deny that any concept not derived from experience could validly apply to objects. ${ }^{1}$

That the deduction is meant to refute skeptical empiricism can seem to be suggested by its apparent argumentative form. Though the two editions' versions of this argument differ substantially, they are both preceded by the same sketch. Here, Kant says: "The objective validity of the categories as a priori concepts rests...on the fact that...through them alone does experience become possible" (KrV, A 93/B 126). ${ }^{2}$ If it can be shown that the application of the categories to objects is a condition on the possibility of experience, then the argument would seem to have overwhelming force. Acceptance of its conclusions would seem to be inevitable, since it seems that no one could deny that experience is possible. Presumably, even skeptical

\footnotetext{
${ }^{1}$ For this interpretation, see (Bennett 1966, 100-102); (Henrich 1989, 37-38); (Forster 2010, 40-41); (Walker 1999, 13). For the interpretation that deduction is meant to refute a 'Cartesian skeptic,' who doubts that experience can yield knowledge of mind-independent objects, see (Brueckner 1984, 197); (Guyer 1987, 67); (McCann 1985, 71); (Rorty 1970, 207); (Strawson, 1966 [2002], 88, 97); (Stroud 2000, 9-10). For 'Pyrrhonian skeptic' interpretations, see (Forster 2010, 44ff); (Stern 2008, 273ff).

Kant usually speaks of "scepticism" or "doubt" in connection to Hume and empiricism. See KrV, A ix-x, B 19-20, B 22-23, B 127-128, A 758-769/B 786-797; KpV, AA 5: 12-14, 50-57; Prol, AA 4: 256-264, 272, 310-313. I thus focus on skeptical empiricism.

2 In quoting Kant's works in English, I use Kemp Smith's translation of KrV, Gregor's translation of KpV, and Hatfield's translation of Prol; see References for bibliographical details.
} 
empiricists would be compelled to accept the conclusion, and so be forced to give up their skepticism about the application of pure concepts, like the categories.

Over time, this picture has come to look naïve to many. Less charitable readers have attributed the naïveté to Kant, arguing that he fails to acheive his aim of refuting the skeptical empiricist, because such a figure would resist his premise that the objective validity of the categories conditions all possible experience. ${ }^{3}$ More charitable readers have attributed the naïveté to the picture, acknowledging that Kant would not expect empiricists to accept the premises, but denying that the deduction is meant to refute such figures. ${ }^{4}$

Recently, some have called for a reevaluation of the situation in light of a survey of the historical figures and texts which influenced Kant's thought. This has led some to think that Kant was right after all to expect the empiricist would accept his premises, and so be refuted..$^{5}$ But others still deny that this was Kant's aim. ${ }^{6}$ There remains little consensus about whether Kant intends his deduction to refute skeptical empiricism. ${ }^{7}$

I think both sides are missing something important here. Both have assumed that the deduction can only refute empiricism if the empiricist accepts its premises while believing that empiricism is true. But that is not how Kant sees things. For Kant sees his deduction as offering the skeptical empiricist a way out of her skepticism, even if it deploys premises she would not accept while holding fast to her empiricism. This can sound fantastical. But, I argue, Kant is reasonable to think this, given his understanding of the sources of skeptical empiricism.

In the next section, I discuss Kant's claim that skeptical empiricism is a stagnated stage in the development of reason towards critique. In $\S 3$, I argue that Kant's deduction offers the

\footnotetext{
3 See (Stroud 2000, 24); (Guyer 1987, 68).

4 See (Ameriks 2003, 64); (Engstrom 1994, 370-376); (Hatfield 2003, 178-184).

5 See (Sommerlatte 2016, 448-450).

6 See (Dyck 2011); cf. (Watkins 2004). For a rejoinder to both, see (Chance 2013).

7 Both sides are generally concerned with what might be called an 'internal refutation' of skeptical empiricismnamely, one whose premises the empiricist could accept. I follow this usage.
} 
empiricist what she would need to progress - namely, an explanation of the possibility she fails to comprehend. In $\S 4$, I respond to the worry that the empiricist would fail to be moved by this explanation, by showing that Kant thinks that her conviction in empiricism is necessarily unstable. The deduction, I conclude, offers a way out of skeptical empiricism, without compelling it.

\section{Progress, haste, and despair}

Kant's first mention of the "sceptic" in the Critique appears within a discussion of the historical development of metaphysics from dogmatism towards "critique" —namely, "a tribunal which will assure to reason its lawful claims, and dismiss all groundless pretensions, not by despotic decrees, but in accordance with its own eternal and unalterable laws" (KrV, A ix-xii). Skeptics are here described as reacting against the innumerable and unruly disputes between warring dogmatists. In this regard, the skeptics, like Kant, acknowledge and criticize the lawlessness of the dogmatists' reigns. This represents a growth in maturity, but one that stagnates in a "doubt" about the possibility of a lawful metaphysics. ${ }^{8}$

Kant seems hostile to the skeptics in this discussion. He says, "Happily they were few in number" (KrV, A ix). But elsewhere he sees the skeptic as playing an important role in the progress of metaphysics. "The sceptic," he says, "is thus a taskmaster who constrains the dogmatic reasoner to develop a sound critique of the understanding and reason." In this way, the skeptic "prepares the way” to critique (KrV, A 769/B 797).

The same favorable tone pervades Kant's discussion of "the most ingenious of all the sceptics": Hume. Kant portrays Hume more as an "acute" ally than an adversary (KrV, A 764/B 792, A 767/B 795). For example, Hume is seen as "arguing quite consistently" for some of the

\footnotetext{
8 This is not to deny that one of Kant's main aims in the Critique is to show that we cannot have theoretical knowledge of the topics that most animate dogmatic metaphysicians - namely, God, freedom, and the immortal soul. In the end, though, Kant "promises to metaphysics...the secure path of a science" (KrV, B xviii-xix). He attempts to explain the possibility of a more limited kind of metaphysics, or at least synthetic a priori knowledge of objects. These are the principles discussed in the Analytic of Principles, including, famously, the principle that all events have a cause, which Kant viewed Hume as denying.
} 
negative results of critique, like the impossibility of the application of concepts "beyond the limits of experience" (KrV, B 127). ${ }^{9}$

Hume, and skeptics in general, go awry, Kant thinks, when they take the censure of dogmatism too far, and decide that metaphysics has no prospects: "[W]hile rightly denying to the understanding what it cannot really supply, they go on to deny it all power of extending itself $a$ priori” (KrV, A 767/B 795). Skepticism then arises in “despair as regards satisfaction of reason's most important aim”-namely, answering metaphysical questions (Prol, AA 4: 271).

Kant's main criticism of Hume is that he is "overly hasty" in giving up on the possibility of metaphysics (Prol, AA 4: 258). He complains that Hume's verdict on the application of pure concepts, and so on the possibility of synthetic a priori knowledge, is made "in spite of his never having tested it as a whole" (KrV, A 767/B 795).

What did Hume hastily overlook? What "never occurred to Hume," Kant says, is the proper "relation of the understanding to experience" - that is, that "the pure concepts of the understanding...[are] not [related] in such a way that they are derived from experience, but that experience is derived from them" (Prol, AA 4: 313; KrV, B 127). In other words, Hume failed to entertain Kant's Copernican turn — “the new point of view" which Kant thinks "enables us to explain how there can be knowledge a priori" (KrV, B xix).

Kant's diagnosis here suggests that an appropriate response to the skeptical empiricist is to show her that empiricism is not her last resort. If she is given a way of comprehending the possibility that the understanding's pure concepts make possible the objects of experience, she could progress beyond her skepticism and to critique.

\section{The deduction's explanatory dimension}

I will now argue that a crucial dimension of the deduction is an explanation of just the possibility which the skeptical empiricist overlooks.

\footnotetext{
${ }^{9}$ Here, I am setting aside Kant's practical application of concepts to supersensible objects.
} 
In a section entitled "The Principles of Any Transcendental Deduction" (KrV, B 116), Kant defines a transcendental deduction as "the explanation of the manner 10 in which concepts can thus relate a priori to objects" (KrV, A 85/B 117, my italics).

An "explanation of the manner" in which certain concepts relate a priori to objects can sound too unambitious a goal to someone who thinks the deduction is meant to refute certain skeptics. I speculate that this is why the definition of a transcendental deduction has not received due attention. Yet this definition's portrayal of the deduction as "explanatory" is by no means isolated: In the first edition preface, for example, Kant says the deduction will "expound and render intelligible ${ }^{11}$ [the] objective validity" of the categories ( $\mathrm{KrV}, \mathrm{A}$ xvi-xvii, my italics). At the beginning of the first edition's deduction, Kant says that "the understanding, ... as a faculty of knowledge that is meant to relate to objects, calls for explanation ${ }^{12}$ in regard to the possibility of such relation" (KrV, A 97, my italics). At its end, Kant says that the goal of "the transcendental deduction of the categories [was] to render comprehensible ${ }^{13}$ this relation of understanding...to all objects of experience" (KrV, A 128, my italics).

Such claims also appear in the Critique's second edition: In a carefully worded, onesentence "outline" of the second edition's deduction, Kant says, "The deduction is the exposition [or exhibition, Darstellung] of the pure concepts of the understanding... as principles of the possibility of experience" (KrV, B 168, my italics). The word 'Darstellung' evokes setting forth something tangible for viewing or surveying, as one does in laying out a blueprint for the building of a house. Such an exhibition makes the structure of something clear by the arrangement of what it sets forth. ${ }^{14}$ Plausibly, an exhibition of this sort is exactly what is

\footnotetext{
10 Erklärung der Art.

11 dartun und begreiflich machen.

12 Erläuterung.

13 begreiflich machen.

14 Compare to 'Darstellung' and cognates at KrV, B xxxviii, B 156, A 562/B 590, A 608/B 636.
} 
requested when Kant asks "how,"15 not whether, "metaphysics as science" or "synthetic a priori knowledge is possible" (KrV, B 19-22, my emphasis; Prol, AA 4: 276-280).

A full defense of this interpretation would have to say more about how the content of the deduction is supposed to "exhibit" and "render intelligible" the understanding's a priori relating to the objects of experience. This would require a more detailed exploration of the deduction than I can provide in a brief paper, and is the subject of future work. ${ }^{16}$ I want instead to focus on the anti-skeptical promises of the deduction on this interpretation.

\section{The instability of skeptical empiricism}

The deduction offers the skeptical empiricist a way out of her skepticism by providing her with an explanation of a possibility she overlooked. If she is receptive to this explanation, she could come to understand how pure concepts can validly apply to objects, and then give up both her skepticism and her empiricism.

But will she be receptive? An affirmative answer may seem hopelessly naïve, and so unattributable to a shrewd thinker like Kant. Kant's explanation in the deduction is an explanation of how concepts apply a priori to the objects of experience. The skeptical empiricist denies precisely this application. Why would she even listen to an explanation of what she denies? Such an explanation would seem to leave her cold. Kant's expecting otherwise may seem tantamount to expecting a sudden, unexplained conversion. I doubt, however, that this interpretation of Kant's expectations forces us to view him in a poor light. Quite the contrary: Kant's hope reflects a keen understanding of skepticism and its sources.

Kant's perhaps most penetrating treatment of skeptical empiricism appears in a rich yet seldom discussed passage near the end of his first Critique, entitled "The Impossibility of a Sceptical Satisfaction of Pure Reason in its Internal Conflict" (KrV, A 758-769/B 786-797). As Kant sees it, the skeptical empiricist who pretends to be satisfied with her empiricism is in bad

\footnotetext{
15 wie.
}

16 See my manuscript "Kant's Offer to the Skeptical Empiricist." 
faith. The desire to acquire synthetic a priori knowledge is a basic and inevitable "natural disposition" of human reason ( $\mathrm{KrV}, \mathrm{B} 22)$ : We humans are "impetuously driven by an inward need to questions such as cannot be answered by empirical employment of reason" ( $\mathrm{KrV}, \mathrm{B} 21)$. This implies that the skeptical empiricist, who in Kant's eyes has given up on answering these questions, is necessarily at war with herself. It follows that, in some sense, the skeptical empiricist is always ready to give up her skepticism, if the way to acquiring such knowledge were to become clear. What Kant offers in his deduction, then, would give her what she really yearns for-an illustration of the possibility of the natural enterprise that she prematurely abandoned only out of frustration.

Of course, for Kant's deduction to inspire this movement, the skeptic would have to entertain aspects of Kant's philosophy that, according to her empiricism, she should resist—for example, Kant's Copernican turn. The skeptic may not always be willing. When she isn't, Kant has a few tactics. He can, for example, push his view that the claims of mathematics are synthetic a priori. Even Hume, he thinks, would rather give up his skeptical empiricism than our pretensions to mathematical knowledge (KrV, B 4-5, 19-20; Prol, AA 4: 272, 4:260).17 I presume, however, that Kant thought these tactics for attracting the skeptic's interest are ultimately inessential. For, according to Kant, a "sceptical satisfaction of pure reason" is "impossible." The skeptic's dissatisfaction will periodically or eventually creep through the cracks. And while the skeptic feels dissatisfied with her position, she may become a more sympathetic listener.

Why does Kant think that the skeptic can never successfully purge the urge to metaphysics? Kant's answer seems to be that the Humean skeptic has no stable, conclusive reason to doubt the possibility of synthetic a priori knowledge (including potential metaphysical knowledge). Of course, the empiricist tenet that all synthetic knowledge is gained through experience would, if known, provide a conclusive reason to give up on metaphysics. But Kant is not worried about this possibility. For he thinks that if the tenet is true, then we cannot know it. Kant says:

${ }^{17}$ It is not clear that Kant is right about this. For a response on behalf of Hume, see (Thielke 2015). 
Nothing worse could happen to [the development of systems of synthetic a priori knowledge] than that someone should make the unexpected discovery that there is and can be no [synthetic] a priori

knowledge ${ }^{18}$ at all. But there is no danger of this. It would be tantamount to someone's wanting to prove by reason that there is no reason. ... It is an outright contradiction to want to extract necessity from an

empirical proposition (ex pumice aquam) and to give a judgment, along with necessity, true universality.

$\mathrm{KpV}$, AA 5: 12

For Kant, the empiricist's tenet would have to hold a priori, given its universal scope: "experience never confers on its judgments true or strict... universality" (KrV, B 3-4). The tenet is also clearly synthetic, since the predicate 'gained through experience' is not already contained in the concept of synthetic knowledge. So the tenet would be synthetic a priori, and so provide a counterexample to itself, if known.

Kant thinks this shows that the empiricist's tenet is liable "to be doubted, as being based only on facts which are contingent" (KrV, A 767-768/B 795-796). The fact that attempts at metaphysical systems have so far failed, or have seemed to, does not conclusively oblige us to lose hope. For Kant, no empirical finding could. And so as long as the skeptical empiricist doubts the possibility of synthetic a priori knowledge, she effectively doubts the possibility of knowing what her tenet asserts. To be sure, Kant thinks it is epistemically possible that reason could determine that some or all metaphysical questions are unanswerable. But reason could only do so through self-critique, not through the empiricist's tenet.

The result is that nothing locks the skeptical empiricist into her view beyond her despairborn doubt. That suggests that a skeptical empiricist may, at times, gain some distance from her conviction in empiricism. She may then be wrested out of her despair by an explanation that satisfyingly "renders intelligible" synthetic a priori knowledge. As I have suggested, Kant's deduction presents a detailed illustration of a possible relationship between concepts and objects which he thinks empiricists like Hume have so far failed to entertain. It is reasonable to think, then, that Kant's vivid illustration of this relationship could engage the skeptic's imagination, and get her to comprehend the possibility that she previously did not see. She could then move beyond her skepticism with adventurous energies restored.

${ }^{18}$ Following Kemp Smith, I translate 'Erkenntnis' as 'knowledge' in place of Gregor’s 'cognition.' 
Here, an objection looms. If what I say is right, why did Kant's Critique not eradicate skeptical empiricism, a view which lives on in many guises today?

One partial answer is that Kant failed to achieve his goal of shedding light on the possibility that the skeptic overlooked, or succeeded only partially without eradicating obstructions and obscurities. The deduction is, after all, notoriously difficult.

Another answer is that certain moods and attitudes can make the skeptics among us obstinate and poor listeners. A skeptic may, for instance, find some perverted contentment in her despair and so be left cold by opportunities to emerge from it, like the slothful unrequited lover who enjoys his dissatisfaction. Again, a skeptic may take pride in her refusal to listen to people outside her 'in'-group, like dissenters proud of flouting the status quo. Such pseudo-satisfactions, and the personalities and moods which tend toward them, may postpone the skeptic's natural urge to have metaphysical questions answered.

Kant's deduction may fail to wrest a skeptic out of these personalities and moods. But it is extreme to see this as a flaw. Probably no argument or rhetoric can appeal to every uncooperative character. The deduction still offers skeptical empiricists a way out of their predicament, whether or not they are consistently open to it.

\section{Conclusion}

Many philosophers invoke Kant's name and spirit when attempting ambitious refutations of skepticism. They model their arguments on the apparent form of the deduction, thinking this will imbue them with compelling force. ${ }^{19}$ Perhaps this strategy can succeed.

But we must not let it overshadow a less aggressive, more cordial response to skepticism. This is to offer the skeptic a way of looking at things that she overlooks - one which illustrates

${ }^{19}$ See (Strawson 1959, 62-63); (Putnam 1981, 16); (Korsgaard 2009, 32-33). 
or explains the possibility of what she doubts or denies. I have argued that we can find this friendly sort of offer in Kant's deduction. And I think that if we hold Kant's offer in mind, we will be able to see various other responses to skepticism along roughly the same lines. This can offer us an easily overlooked strategy for responding to, and curing, skepticism.

\section{References}

Ameriks, Karl (2003): Interpreting Kant's Critiques. Oxford: Clarendon Press.

Bennett, Jonathan (1966): Kant's Analytic. Cambridge: Cambridge University Press.

Brueckner, Anthony L. (1984): “Transcendental Arguments II”. In: Nô̂s 18, 197-225.

Chance, Brian A. (2013): “Causal Powers, Hume's Early German Critics, and Kant's Response to Hume". In: Kant-Studien 104, 213-236.

Dyck, Corey W. (2011): “Kant's Transcendental Deduction and the Ghosts of Descartes and Hume". In: British Journal for the History of Philosophy 19, 473-496.

Engstrom, Stephen (1994): “The Transcendental Deduction and Skepticism”. In: Journal of the History of Philosophy 32, 359-380.

Forster, Michael N. (2010): Kant and Skepticism. Princeton, NJ: Princeton University Press.

Förster, Eckart (1989): Kant's Transcendental Deductions: The Three Critiques and the Opus Postumum. Palo Alto, CA: Stanford University Press.

Goldhaber, Charles (unpublished ms): "Kant's Offer to the Skeptical Empiricist."

Guyer, Paul (1987): “The Failure of the B Deduction”. In: The Southern Journal of Philosophy 25. Suppl. 1, 67-84.

Hatfield, Gary (2003): “What Were Kant's Aims in the Deduction?” In: Philosophical Topics 31. No. 1 \& 2, 165-198. 
Henrich, Dieter (1989): “Kant's Notion of a Deduction”. In Henrich, Dieter: Kant's

Transcendental Deductions: The Three Critiques and the Opus Postumum. Palo Alto, CA:

Stanford University Press, 29-46.

Kant, Immanuel (1781/7 [1929]): Critique of Pure Reason. Norman Kemp Smith (Tr.). New York, NY: Palgrave Macmillon.

Kant, Immanuel (1783 [2004]): Prolegomena to Any Future Metaphysics: That Will Be Able to Come Forward as Science. Gary Hatfield (Tr.). Cambridge: Cambridge University Press.

Kant, Immanuel (1788 [1996]): Critique of Practical Reason. Mary Gregor (Tr.). In: Kant, Immanuel: Practical Philosophy. Mary Gregor (Ed.). Cambridge: Cambridge University Press.

Korsgaard, Christine M. (2009): Self-Constitution: Agency, Identity, and Integrity. Oxford: Oxford University Press.

McCann, Edwin (1985): “Skepticism and Kant's B Deduction”. In: History of Philosophy Quarterly 2, 71-89.

Putnam, Hilary (1981): Reason, Truth and History. Cambridge: Cambridge University Press.

Rorty, Richard (1970): “Strawson's Objectivity Argument”. In: The Review of Metaphysics 24, 207-244.

Sommerlatte, Curtis (2016): "Empirical Cognition in the Transcendental Deduction: Kant's Starting Point and His Humean Problem". In: Kantian Review 21, 437-463.

Stern, Robert (1999): Transcendental Arguments: Problems and Prospects. Oxford: Clarendon Press.

Stern, Robert (2008): “Kant's Response to Skepticism”. In: Greco, John (Ed.): The Oxford Handbook of Skepticism. Oxford: Oxford University Press, 265-285.

Strawson, P. F. (1959): Individuals: An Essay in Descriptive Metaphysics. London: Routledge.

Strawson, P. F. (1966 [2002]): The Bounds of Sense. New York, NY: Taylor \& Francis. 
Stroud, Barry (2000): “Transcendental Arguments”. In: Stroud, Barry, Understanding Human Knowledge: Philosophical Essays. Oxford: Oxford University Press, 9-25.

Thielke, Peter (2015): “Turnabout is Fair Play: A New Humean Response in the Old Debate with Kant". In: Hume Studies 41, 263-288.

Walker, Ralph C. S. (1999): "Induction and Transcendental Arguments". In: Walker, Ralph C. S.:

Transcendental Arguments: Problems and Prospects. Oxford: Clarendon Press, 13-29.

Watkins, Eric (2004): “Kant's Model of Causality: Causal Powers, Laws, and Kant's Reply to Hume". In: Journal of the History of Philosophy 42, 449-488. 